\title{
Using Institutional Resources and Agency to Support Graduate Students' Success at a Hispanic Serving Institution
}

\author{
Natalie A. Tran ${ }^{1, *}$, Gaetane Jean-Marie ${ }^{2}$, Katherine Powers ${ }^{3}$, Sean Bell ${ }^{4}$ and Kimberly Sanders ${ }^{5}$ \\ 1 College of Education, California State University, Fullerton, 800 N. State College Blvd., \\ Fullerton, CA 92831, USA \\ 2 College of Education, University of Northern Iowa, 1227 West 27th Street, Cedar Falls, IA 50614, USA; \\ gaetane.jean-marie@uni.edu \\ 3 Office of Graduate Studies, California State University, Fullerton, 800 N. State College Blvd., \\ Fullerton, CA 92831, USA; kpowers@fullerton.edu \\ 4 College of Health and Human Development, California State University, Fullerton, \\ 800 N. State College Blvd., Fullerton, CA 92831, USA; sean.bell@csu.fullerton.edu \\ 5 College of Education and Human Development, University of Louisville, Louisville, KY 40292, USA; \\ kimberly.sanders@louisville.edu \\ * Correspondence: natran@fullerton.edu; Tel.: +1-657-278-5481; Fax: +1-657-278-3110
}

Academic Editor: Lorri J. Santamaría

Received: 2 November 2015; Accepted: 2 August 2016; Published: 16 August 2016

\begin{abstract}
There is a growing body of evidence that links increased social capital to minority student success in college. This paper seeks to expand specifically on the graduate experience of underrepresented minorities (URM) at a Hispanic Serving Institution (HSI) using the social capital framework. In a cross-sectional survey, 198 graduate students retrospectively considered the role of institutional resources and agents in their success towards graduation. Data revealed that motivational factors such as a sense of personal achievement, family support, peer support, career promotion, supportive faculty, program satisfaction, and faculty mentor played critical roles in the success of graduate students at HSI. Specifically, Latino students are more likely to report that faculty mentors played a significant role in their success compared to their non-Latino peers $\chi^{2}(1, N=195)=5.33, p=0.02$. Latinos/as were also more likely to use writing support services than their non-Latino/a peers $\chi^{2}(2, N=190)=7.59, p=0.02$. By identifying and increasing access to institutional resources and agents, underrepresented minorities in post-baccalaureate programs may encounter less barriers to graduate degree success.
\end{abstract}

Keywords: graduate students; social capital; Hispanic Serving Institution; Latino students; underrepresented minorities

\section{Introduction}

As society progresses in the 21st century, universities and colleges face profound challenges to refine the role of higher education in the U.S. [1]. One area that merits further consideration as demographic shifts continue to reflect a more diverse society [2-8] is the question of who will attend or have access to college. Research indicates that the college-going population has increased in its racial and ethnic diversity over the last several years [6-8]. In particular, over the past four decades, more students from historically underrepresented groups have enrolled in U.S. colleges and universities [5,9]. Specifically, minority student enrollment increased by 146 while total enrollment increased by about 40 percent overall; in essence Hispanic undergraduate enrollment greatly outpaced other racial/ethnic groups $[6,9]$. 
An example of this disparity that has been well documented is the lack of diversity in graduate Science, Technology, Engineering, and Mathematics (STEM) programs and higher education institutions lag behind in diversifying their student population. This challenge has promoted further investigation into this matter [10]. The challenge to increase enrollments of diverse students in graduate programs is one that institutions grapple with to respond to shifting demographics of society. Examining this further, Palmer, Maramba and Dancy [10] (p. 1) assert that the STEM workforce demands a more diverse working population in order to be viable: "Various reports, researchers, policymakers, and national leaders have expressed the importance of the United States increasing its production of workers skilled in science, technology, engineering, and mathematics (STEM) to be competitive in the global economy". While we highlight the disparities at both the undergraduate and graduate levels, the focus of our study is on the latter, emphasizing factors that affect the success of graduate students of color in general.

Zusman [1] (p. 25) asserts that "a larger proportion of the population than ever before are participating in some form of postsecondary education—but college access and completion remain inadequate for traditionally underserved groups, especially the poor, ethnic minorities, and older students". The opportunity for all students to have access to public higher education regardless of race, ethnicity, socio-economic status or preparation is the fundamental principle of U.S. higher education $[9,11]$. This principle is manifested in the ideology that citizens need a choice of educational opportunities, institutions, and programs with minimal geographic and demographic gaps so that access does not become a hollow promise [12]. While higher education is seen as a broader social good $[13,14]$, there are ongoing access barriers that make it difficult for historically underserved groups, this has a detrimental effect as underrepresented students are increasing in their proportion of the college-age pool [1].

The backlash against affirmative action reflected in current litigations in states such as Texas, California and Washington and its governing board have created barriers for underrepresented students to have access to higher education. This further compounds the challenges of recruiting talented minority students-undergraduate and graduate to pursue higher and professional education; and thus remains an ongoing concern for higher education [13]. One strategy to mitigate this situation is to provide students with the adequate support they need to be successful. The purpose of this study is to examine factors that contribute to the success of graduate students with an emphasis on the role of faculty mentor in supporting graduate students at a Hispanic Serving Institution.

\section{Literature Review}

\subsection{Stratification among Education Achievement in Higher Education for Students of Color}

In 1862, the Morrill Land Grant Act was passed and its purpose was to broaden the curriculum inclusive of agricultural and mechanical arts which consequently diversified higher education institutions to a larger and more heterogeneous student body, higher state costs, and a greater emphasis on the notion of university public service [15]. Since its inception, state policymakers in the U.S. have been engaged in ongoing redesign of their public higher education systems $[11,13]$. Such visible efforts sought to accelerate mission differentiation in various states [15] and develop academic policies that increase the stratification of students and academic programs [11]. Poignantly raising concerns about a more pro-active stance against making higher education more accessible to underserved populations, Zusman [1] (pp. 13-14) asserts that:

"If policy makers and higher education leaders in effect "change the rules" just when a new generation of students-less white, less middle class-is prepared to enter college, questions are raised about equity in a democratic society, as well as risks to social stability. Reducing access to higher education also raises concerns about meeting society's economic and civic needs at a time of increasing technological, economic, social, and political complexity and interdependence. Slowing or even reversing the country's 
historic movement toward universal access to higher education is especially problematic because it is being driven largely by governmental and institutional decisions made on financial grounds, rather than by explicit policy decisions on higher education access and participation."

Central to the debate is the diminishing opportunity for universal access to education. Today, questions have arisen about the usefulness of mass access and about whether higher education is a public or a private good which questions who benefits—society or the individual-and therefore, who should bear the cost [13]. The 2006 report of the Spellings Commission (Charting the Future of U.S. Higher Education), established by Secretary of Education Margaret Spellings, pushed institutions to be more affordable and accessible, and accrediting agencies to produce more information relevant to accountability for student learning [16]. Beyond accessibility and affordability of college, attention must be paid to the stratification of underserved minority students. Particularly, campus climate research is further needed to serve as a foundation for institutional change [17] and improve the overall college experience for students.

In Rankin and Reason's [18] study on the perceptions of how students of color and White students perceive campus climate for underrepresented groups, among the findings, they found that students of color experienced harassment such as offensive, hostile, or intimidating behavior that interfered with their learning, at higher rates than White students. Further, students of color perceived the climate to be more racially hostile and less accepting than their White counterparts. Findings from campus climate studies justify the need for increasing structural diversity, provide empirical evidence as to why diversity improves educational benefits, and create a basis upon which data-driven decisions can be made about climate concerns and social justice issues [19]. These findings are consistent in the research synthesis by Quayle and Harper [20] on student engagement which indicates that disparities in persistence and graduation rates of students from historically underrepresented groups continue as more report being alienated and rebuffed as they attempt to navigate campus settings that they perceive privilege some groups over others. Similar to these scholars, Kuh, Kinzie, Schuh and Whitt [16] argue that institutional policies, practices, and learning environments can encourage and support, or discourage and hinder students in achieving their educational objectives. More specifically, with the changing demographics for the graduate student population, there is a need to understand and reform institutional behaviors and practices to serve a large numbers of low-income, first-generation, and students of color-this is the case for Hispanic Serving Institutions, institutions serving at least $25 \%$ of Hispanic students, [21]. Factors that influence the success of low-income, first-generation, and students of color in post-secondary education include: (a) cultural and academic incongruity; (b) validation from others regarding their academic propensity; (c) spirituality that can shape their values and provides inner strengths to persist their goals; and (d) experiencing an inclusive, multicultural curriculum in their academic programs [22].

In considering the educational trajectory of undergraduate and graduate students of color, the existing body of knowledge purport that a number of barriers exist to their pursuit. But, for those who experience success, they do so through their agency of social capital which serves as the anchor for transcending the challenges.

\subsection{Social Capital Theory}

With the turn of the century came a new understanding of capital that extended beyond the classical monetary embodiment into what is known as social capital, or the nonmonetary value of influence and power. Pierre Bourdieu had the first contemporary definition of social capital. Bourdieu defined the concept as "the aggregate of the actual or potential resources which are linked to possession of a durable network of more or less institutionalized relationships of mutual acquaintance or recognition" [23] (p. 248). Several other key authorities have either evolved the definition of social theory or lead the way for others. At first, authors like economist Glen Loury had challenged the conventional individualistic economic theories to include social theories of inherited capital from 
family generations or race [24]. While Bourdieu and Loury may have laid the foundations for the conceptualization of social capital, many authors have expanded upon this concept yet a clear definition of social capital has been elusive. Portes' attempt to consolidate the literature on social capital has left us with a working definition: "the ability of actors to secure benefits by virtue of membership in social networks or other social structures" [25].

Still, others have developed definitions that emphasize the institutional agents within social capital. For example, Coleman defined social capital by its function as a variety of entities with two common elements, that is, "they all consist of some aspect of social structures, and they facilitate certain action of actors whether persons or corporate actors within the structure" ([26], p. S98; [27], p. 302). Foley and Edwards [28] pointed out the equal access to social capital-that not all social capital is created equal. In addition, Portes [25] also pointed out the interconnectedness between social capital and cultural capital. In his study, he found that after controlling for student age, sex, family, social economic status, English proficiency, and length of U.S. residence, measures of social capital for immigrant children (such as intact family, parental involvement and network closure) decreased in their effect on students' academic performance significantly. Nationality was another significant predictor after controlling for the variables mentioned above for academic performance, with Chinese and Korean nationalities having a strong margin of improvement compared to those of Mexican nationality, who on average underachieved [25]. The results of this empirical study suggest that differences in how students of Asian and Mexican descents are viewed and treated may account for differences in performance outcomes-thus the influence can be attributed to cultural capital and not social capital alone [29].

\subsection{Social Capital in Higher Education and Student Success}

Stanton-Salazar [30] defined social capital as resources or institutional support accessible by students through their social ties to other agents in the institution. Museus and Neville [31] postulated that positive institutional agents for minority students' access to social capital include shared common ground with students, provide holistic support for those students, humanize educational experience, and provide proactive support for those students. More specifically, positive cross-racial experiences and familiarity with diversity issues can counter balances negative experiences, thus enhancing Latino/a students' social and academic connections [32].

While social capital vary in forms and shapes among various student groups across the nation, in general college preparation had support from social networks but lacked individualized, concrete, and comprehensive college planning for underrepresented populations [33]. It follow that early, continuous, and integrated connections with other minority undergrads enhance the development of social capital [31]. Historically Black Colleges and Universities (HBCU) offer abundant social capital that is not typically found in mainstream institutions, particularly, $\mathrm{HBCU}$ provide enhanced, tailored resources that mainstream institutions lack [34]. Empirical evidence suggests that there is a clear relationship between campus leadership, active out-of-class engagement, and social capital among African American male undergraduates [35].

Still, Park [36] found that other ethnic groups look outside of the institution to garner social capital. For example, economic exchanges among various ethnic groups promote interclass contact within Eastern Asian American communities (Korean and Chinese Americans). Religious affiliation and attendance were positively associated with SAT preparation for Korean Americans. Thus, immigrant families who have access to the social capital of churches encourage interclass information and education resources. Finally, social capital among immigrant Vietnamese youth between those who have assimilated into the dominant culture and those who have retained cultural ties differ greatly. In this community specifically, higher retention of cultural values (work ethic, values, involvement with ethic community) results in significantly higher grades, college plans, and academic orientation [37]. 


\subsection{Access to Institutional Resources in Historically White Institutions and Hispanic Serving Institutions}

Efforts to create a more inviting climate for underrepresented groups are critical to the recruitment and retention of undergraduate and graduate students. The literature identified several factors that play a significant role in supporting minority students' educational attainment and institutional satisfaction. In Predominantly White Institutions (PWIs), taking interdisciplinary courses, culturally relevant workshops, participating in research projects, building mentoring networks, and interacting with faculty are factors that influence students of color educational aspirations [38-40]. Faculty-student interactions appear to play a pivotal role not only in academic achievement, student retention, but also institutional satisfaction. However, PWIs struggle with recruiting, admitting, and retaining a diverse student population.

In contrast, Hispanic-Serving Institutions (HSIs), institutions that serve at least $25 \%$ of Hispanic students, have made substantial progress of structural diversity or representation at the student level $[5,38,41,42]$. HSIs represent a growing segment of higher education institutions in the U.S. that serve a high number of Latino students, provide unique learning environments, and have the potential to be instrumental in Latino educational attainment [38]. According to the Hispanic Association of Colleges and Universities [14], 409 institutions met the federal enrollment criterion, enrolling 1,708,391 Hispanics and the majority of Hispanic students are concentrated in a small number of institutions in a few states (np). For example, it was projected that by 2010, California would have over 40 percent of public high school graduates being of Latino background, while just over one-third will be White [1]. Today, more than $50 \%$ of the nation's Hispanics live in California, Florida and Texas. Adding New York, Arizona, Illinois, New Jersey, and Colorado accounts for over 75\% of all Hispanics in the nation [5].

In addition to the structural diversity of HSIs, and despite the lack of resources, they are instrumental in creating a more inviting and supportive campus environments for students of color that are culturally responsive and strive to deploy educational practices that make a difference to student success [38,41]. In most instances, HSIs have a grasp on who its student populations are, what they have the potential to do academically, and what they expect of the institution and themselves [42,43]. They are also able to create remediation programs linked to the specific social, cultural, and educational components that can better support students. Remedial education serves as a means of providing academically underprepared students with the knowledge and skills needed to succeed in college by eliminating or reducing academic deficiencies [41,44]. This reinforced Rendon's [22,45] findings in which a supportive process initiated by faculty and other college agents of socialization in and out of the classroom can foster student success, particularly for historically underserved students.

\subsection{The Role of Faculty Mentor in Facilitating Social Capital}

Two notable studies examined the role of faculty mentoring program in contributing to student success in post-secondary settings. First, in a cross-sectional study, Santos and Reigadas [46] surveyed 32 Latino students in a Faculty Mentoring Program (FMP) to assess their adjustment to a college environment. Demographic information of the Latino sample included gender (75\% female $/ 25 \%$ male), citizenship (90.6\% U.S. born), and first-generation college student status $(70.9 \%)$. Specifically, the researchers investigated the extent to which mentoring could provide both professional and emotional support to college students. They found the following: (1) Students who participated in FMP experienced higher self-efficacy, more concern about succeeding, and had better defined academic goals; (2) Students with mentors from the same ethnic background displayed greater measured outcomes compared to students who were not matched by their ethnicity; (3) Frequency of mentor contact was associated with better college adjustment and increased levels of satisfaction.

Second, Waldeck, Orrego, Plax, and Kearney [47] examined the mentoring relationships between graduate students and faculty. Five criteria were implemented to examine the success of the program: (1) demographics of protégés and mentors; (2) communication initiation strategies; (3) self-evaluations of strategy; (4) functions of relationship; (5) and protégé satisfaction. It is further noted that unlike academic advisors, mentors provide professional skills, unspoken department knowledge, and foster 
professional relationships to that the protégé may advance their academic as well as professional careers. The results $(N=149)$ suggest that while conventional mentoring aims to provide only personal career functions, the majority of student satisfaction came from the psychosocial bonds they created with their mentors. Previous empirical investigations that focus on the social networks of students of color tend to explore student experiences at large research institutions and generally include small sample sizes. Existing studies fail to examine the experiences of minority students at Hispanic Serving Institutions. The current study will address a void in the extant literature by examining the role of institutional resources, including faculty mentorship, in student of color success in graduating.

\section{Methods}

The current study examines graduate students' perceptions of factors that influence their success at an HSI using a cross sectional survey. Descriptive and inferential statistical analyses were used to examine these factors. The following section provides further details of the study sample, instruments, data collection, analysis, and results.

\subsection{Participants}

Of the 821 graduate students who had graduated in spring 2013 from a Hispanic Serving Institution and had been solicited to participate in the survey questionnaire; 216 graduate students from several departments voluntarily completed the survey questionnaire. Approximately $26 \%$ of students who received the email on 8 August 2013, had responded and completed the survey that closed in August 2013. Inclusion criteria included graduate students who were (1) only receiving their master's degree; (2) not in a credential program; (3) not an undeclared post-baccalaureate taking graduate level courses; (4) not admitted to a master's program; and (5) must have graduated during Fall or Spring of 2013. Incentive to complete the survey included a raffle for an android tablet. The participant's age range consisted mainly of 20-29 year olds (54\%) while 30-39 year olds (21\%), 40-49 year olds (11\%), and 50-59 year olds (5\%) made up the rest of the sample. The sample consists of a diverse student population with 43\% White, 22\% Latino, 18\% Asian American and Pacific Islander, $4 \%$ Black, and $13 \%$ other.

\subsection{Measures and Procedure}

The 41-item survey consisted of items describing graduates' experiences at the HSI, degree program, sources of financial support, factors contributed to degree completion, availability of courses, academic support, capstone experiences, perceptions of faculty, support during graduate studies, and campus climate. This survey was developed and distributed by the program directors.

Qualtrics, an online survey service, was used as the means to collect participant responses. Participants were instructed to complete the survey to the best of their abilities and, upon completion of the survey, participants were asked if they would like to participate in a raffle for an android tablet. All surveys results were kept anonymous by removing data of associated emails.

The questions on the survey included the following: "What were the positive factors that kept you in school? Check all that apply." Participants had sixteen options in total to choose from: faculty mentor, career or work advantages (promotion, new job, etc.), sense of personal achievement, research experiences, financial aid, work on campus, having an office on campus, supportive faculty, supportive fellow students/peers, networking, assistance through tutoring, and/or workshops, assistance through counseling, satisfaction in the program, supportive department environment, and family support. Their choice in factors that kept them in school were indicated by using either checking the corresponding box or leaving it unchecked.

When measuring the services graduate students use and their influence, participants were asked "The Office of Graduate Studies offers many services to graduate students, such as writing support, one-on-one tutoring, workshops, counseling, etc." The services to choose from included one-on-one tutoring, writing or academic skills workshops, counseling, and writing boot camps. First, participants 
were assessed to see if they had heard of or utilized a service: "1 = Didn't know it was offered", "2 = Knew this was offered but did not use it", and " 3 = Utilized this service". A follow up question asked "If you utilized any of these services, how beneficial were they?" Using a Likert scale, participants indicated the perceived benefits from the services: " 1 = Not beneficial", " 2 = Somewhat beneficial", and " 3 = Very beneficial".

At the end of the survey, demographic variables that were self-reported included gender, age, ethnicity, grade point average and number of family members with education. Gender could be chosen from male, female, and other options while approximate age was indicated by five options: 20-29, 30-39, 40-49, 50-59, and 60+. Ethnicity was chosen between African American, American Indian, Asian American, Filipino, Mexican American/Chicano(a), Other Hispanic/Latino(a), Pacific Islander, White (non-Latino), and International Student. Approximate GPA when participants graduated through interval categories: 3.00-3.25, 3.26-3.50, 3.51-3.75, and 3.76-4.00. Lastly, participants indicated the number of immediate family members that have associate, bachelorette, masters, and doctorate degrees. All responses were coded and analyzed within SPSS.

\section{Results}

The results were generated using descriptive statistics-frequencies and valid percentages were calculated for gender, age, ethnicity, and GPA whereas the number and mean of family members with education were calculated. To examine differences between Latino and non-Latino graduate students' perceptions of factors that influence their college success, we used cross-tabulation and $\mathrm{Chi}^{2}$ tests. Specifically, we assessed the relationship between Latinos and college retention (16 factors). Another $\mathrm{Chi}^{2}$ test was run to assess the difference between Latinos and non-Latino graduate students and their utilization of services provided by the Department of Graduate Studies (DGS).

\subsection{Descriptive Statistics}

We assessed the relationship between Latinos and non-Latinos across factors that contributed to graduation and institutional services that enhanced graduate student success. Ethnicity was the primary independent variable that consisted of whether a participant was considered Latino; a total of 163 participants $(83.6 \%)$ were considered non-Latino while $32(16.4 \%)$ were considered Latino. Knowledge and participation of DGS and factors that kept students in school were the two dependent variables of interest. Descriptive statistics indicate that that sample has a greater number of female than male students, this disproportion is greater among Latinos/as (75\% female) compared to non-Latinos/as (56\% female). Over 50\% of the graduate students in the sample are between 20 and 29 years old. As expected, about $60 \%$ of the graduate students in the sample earned a GPA of 3.75-4.00. Interestingly, there is a wide range of students whose family members attained advanced degree in post-secondary education with approximately $20 \%$ receiving degrees in each of the following categories: AA, BA/BS, Masters, and Doctorate. Table 1 provides a summary of the participants in the study.

Table 1. Demographics of the study sample.

\begin{tabular}{|c|c|c|c|c|c|c|}
\hline \multirow{2}{*}{ Characteristics } & \multicolumn{2}{|c|}{ Number } & \multicolumn{2}{|c|}{ Latinos } & \multicolumn{2}{|c|}{ Non-Latino } \\
\hline & $N$ & Valid \% & $N$ & Valid \% & $N$ & Valid \% \\
\hline \multicolumn{7}{|l|}{ Gender } \\
\hline Male & 80 & 40.4 & 8 & 25.0 & 71 & 43.6 \\
\hline Female & 118 & 59.6 & 24 & 75.0 & 92 & 56.4 \\
\hline Total & 198 & & 32 & & 163 & \\
\hline \multicolumn{7}{|l|}{ Age } \\
\hline $20-29$ & 108 & 54.6 & 18 & 56.3 & 90 & 55.2 \\
\hline $30-39$ & 51 & 20.8 & 10 & 31.3 & 40 & 24.5 \\
\hline $40-49$ & 29 & 10.8 & 3 & 9.4 & 25 & 15.3 \\
\hline $50-59$ & 10 & 5.1 & 1 & 3.1 & 8 & 4.9 \\
\hline $60+$ & 0 & 0 & 0 & 0 & 0 & 0 \\
\hline Total & 198 & & 32 & & 163 & \\
\hline
\end{tabular}


Table 1. Cont.

\begin{tabular}{|c|c|c|c|c|c|c|}
\hline \multirow{2}{*}{ Characteristics } & \multicolumn{2}{|c|}{ Number } & \multicolumn{2}{|c|}{ Latinos } & \multicolumn{2}{|c|}{ Non-Latino } \\
\hline & $N$ & Valid \% & $N$ & Valid \% & $N$ & Valid \% \\
\hline \multicolumn{7}{|l|}{ Ethnicity } \\
\hline White (non-Latino) & 84 & 43.1 & - & - & 84 & 51.5 \\
\hline Asian American & 29 & 14.9 & - & - & 29 & 17.8 \\
\hline Mexican American/Chicano(a) & 20 & 10.3 & 20 & 62.5 & - & - \\
\hline Other Hispanic/Latino(a) & 12 & 6.2 & 12 & 37.5 & - & - \\
\hline International Student & 11 & 5.6 & - & - & 11 & 6.7 \\
\hline Other & 10 & 5.1 & - & - & 10 & 6.1 \\
\hline African American & 7 & 3.6 & - & - & 7 & 4.3 \\
\hline Filipino & 6 & 3.1 & - & - & 6 & 3.7 \\
\hline American Indian & 2 & 1 & - & - & 2 & 1.2 \\
\hline Decline to state & 14 & 7.2 & - & - & 14 & 8.6 \\
\hline Total & 195 & & 32 & & 163 & \\
\hline \multicolumn{7}{|l|}{ GPA } \\
\hline $3.75-4.00$ & 118 & 59.9 & 20 & 62.5 & 96 & 58.9 \\
\hline $3.51-3.75$ & 45 & 22.8 & 10 & 31.3 & 34 & 20.9 \\
\hline $3.26-3.50$ & 23 & 11.7 & 2 & 6.3 & 21 & 12.9 \\
\hline $3.00-3.25$ & 11 & 5.6 & 0 & 0 & 11 & 6.7 \\
\hline \multicolumn{7}{|l|}{$\begin{array}{c}\text { Number of Family Members } \\
\text { with Education }\end{array}$} \\
\hline $\mathrm{AA}$ & 124 & - & 24 & 24.7 & 99 & 22.2 \\
\hline $\mathrm{BA} / \mathrm{BS}$ & 169 & - & 27 & 28.7 & 140 & 31.5 \\
\hline Masters & 146 & - & 24 & 24.7 & 120 & 27.0 \\
\hline Doctorate & 105 & - & 19 & 20.2 & 86 & 19.3 \\
\hline
\end{tabular}

In Table 2, sixteen factors keeping graduate students in school included sense of personal achievement, supportive fellow students/peers, career or work advantage, supportive faculty, faculty mentor, family support, satisfaction in the program, financial aid, research experiences, supportive department environment, work on campus, networking, having an office on campus, assistance through counseling, and assistance through tutoring and/or workshops. Of the sixteen factors that kept graduate students in school, only the choice of faculty mentor was shown to have a significant difference between the 61 non-Latinos and 19 Latinos as seen in Table 2. There were no statistical significant differences between Latinos and non-Latinos in all other factors. Lastly, among the graduate services offered, writing boot camps consisted of 67 participants (12\% Latino) that said they "did not know this was offered", 115 participants (17\% Latino) said they "new this was offered but did not use it", and 8 participants (50\% Latino) had said "utilized services" (see Table 3).

Table 2. Inferential statistics of influential factors.

\begin{tabular}{|c|c|c|c|c|c|c|c|}
\hline \multirow{2}{*}{ Factors Keeping One in School } & \multicolumn{2}{|c|}{ Latino } & \multicolumn{2}{|c|}{ Non-Latino } & \multirow{2}{*}{ Chi-Squared } & \multirow{2}{*}{ Significance } & \multirow{2}{*}{$\begin{array}{l}\text { Fishers Exact } \\
\text { Significance }\end{array}$} \\
\hline & $n$ & $(\%)$ & $N$ & $(\%)$ & & & \\
\hline Sense of personal achievement & 27 & $(84.4)$ & 133 & $(81.6)$ & 0.140 & 0.708 & \\
\hline Supportive fellow students/peers & 21 & $(65.6)$ & 91 & $(55.8)$ & 1.050 & 0.305 & \\
\hline Career or work advantage & 20 & $(62.5)$ & 84 & (51.5) & 1.292 & 0.256 & \\
\hline Supportive faculty & 20 & $(62.5)$ & 77 & $(47.2)$ & 2.492 & 0.114 & \\
\hline Faculty mentor & 19 & $(59.4)$ & 61 & (37.4) & 5.327 & 0.021 & \\
\hline Family support & 19 & $(59.4)$ & 93 & (57.1) & 0.059 & 0.808 & \\
\hline Satisfaction in the program & 16 & $(50.0)$ & 71 & $(43.6)$ & 0.449 & 0.503 & \\
\hline Financial aid & 14 & $(43.8)$ & 52 & (31.9) & 1.677 & 0.195 & \\
\hline Research experiences & 13 & $(40.6)$ & 44 & $(27.0)$ & 2.403 & 0.121 & \\
\hline $\begin{array}{l}\text { Supportive department } \\
\text { environment }\end{array}$ & 12 & $(37.5)$ & 42 & $(25.8)$ & 1.839 & 0.175 & \\
\hline Work on campus & 8 & $(25.0)$ & 22 & (13.5) & 2.719 & 0.099 & \\
\hline Networking & 8 & $(25.0)$ & 46 & $(28.2)$ & 0.139 & 0.710 & \\
\hline Having an office on campus & 4 & (12.5) & 12 & (7.4) & & & 0.306 \\
\hline Assistance through counseling & 3 & $(9.4)$ & 11 & (6.7) & & & 0.706 \\
\hline $\begin{array}{l}\text { Assistance through tutoring, } \\
\text { and/or workshops }\end{array}$ & 2 & $(6.2)$ & 10 & $(6.1)$ & & & 1.000 \\
\hline
\end{tabular}


Table 3. Crosstabulation of Latinos and graduate studies services.

\begin{tabular}{cccccc}
\hline Knowledge \& Participation of DGS Services & Non-Latinos & Latinos & Total & Chi-Squared & Significance \\
\hline Writing Boot Camps & & & & & $0.022 *$ \\
Didn't know it was offered & 59 & 8 & 67 & 7.591 & 0.905 \\
Knew it was offered but did not use it & 96 & 19 & 115 & & \\
Utilized this service & 4 & 4 & 8 & & 0.517 \\
Writing or Academic Skills Workshops & & & & \\
Didn't know it was offered & 19 & 113 & 27 & 0.200 & \\
Knew it was offered but did not use it & 3 & 22 & 6 & & 0.572 \\
Utilized this service & 22 & 135 & 33 & & \\
Counseling & 24 & 7 & 31 & & \\
Didn't know it was offered & 105 & 20 & 125 & & \\
Knew it was offered but did not use it & 29 & 4 & 33 & & \\
Utilized this service & & & & \\
One-on-One Tutoring & 62 & 14 & 76 & 1.117 & \\
Didn't know it was offered & 84 & 16 & 100 & & \\
Knew it was offered but did not use it & 13 & 1 & 14 & & \\
Utilized this service &
\end{tabular}

Note: * Significance at level $p<0.05$.

\subsection{Inferential Statistics}

Table 2 represents the inferential statistics that examine the relationship between ethnicity and factors keeping one in school and graduate study service utilization. Crosstabs showed that Latino students indicated that faculty mentors played a significant role in their success than non-Latino peers $\chi^{2}(1, N=195)=5.33, p=0.02$. The low $p$-value indicates that there is a significant difference between non-Latinos and Latinos when choosing faculty as a major factor for keeping one in school, with Latinos/as more likely to report that faculty mentors play a role in their decision to stay in school. No significant differences were observed between Latinos/as and their non-Latinos/as peers in other factors. Table 2 provides a summary of the results. Latinos/as were also more likely to use writing support services than their non-Latino/a peers $\chi^{2}(2, N=190)=7.59, p=0.02$. This low $\mathrm{p}$-value indicates that there is also a significant difference between Latinos and non-Latinos when it comes to utilization of writing boot camps as graduate students, with Latinos/as more likely to report using student support services, particular for improving writing skills. No significant differences were observed between Latinos/as and their non-Latinos/as peers in utilizing other student support services including: writing or academic skills workshops, counseling, and one-on-one tutoring. Table 3 provides a summary of the results.

\section{Discussion}

\subsection{Students of Color and Social Networks in Higher Education}

A growing body of literature underscores the significance of social networks in facilitating positive outcomes for students of color (see [30,31,48-50]). A social network, defined in the literature as a social structure consisting of a group of social actors and the pattern of ties linking them together [51], benefits students in a myriad of ways. When these networks are facilitated by frequent, positive interactions with faculty in the form of mentorship, they have been shown to predict numerous educational outcomes and attainment $[17,52,53]$. For example, focusing on Black students at a Historically Black College, Fontaine [49] demonstrates that faculty-student interaction is a strong predictor of persistence. For graduate students specifically, interactions with faculty can be the most important aspect of their graduate experience [54]. Quality guidance and mentorship from faculty, characterized by social, emotional, and academic support [53], also provide the added benefit of an established social network.

While all students benefit from mentorship and access to an expanded social network, students identifying as members of racial and ethnic minorities, may benefit more than White students, because on average they enter college with smaller social networks than their White counterparts [55]. 
Scholars utilizing social capital frameworks to examine the role of institutional agents, especially faculty, in the experiences of college students of color emphasize the importance of agents in creating positive student outcomes [31,34,56,57]. For example, Avery and Daly [56] suggest that high-risk college students, such as racial minorities, rely upon social networks, including relationships with advisors and faculty, in their pursuit of social capital, and these networks were a key factor in their success. Through their relationships with faculty, students learn how to navigate campus bureaucracy and access resources. Participants in Avery and Daly's study reported that students lacked relationships with faculty and thus were unable to connect with many existing campus resources. Mentors play an integral role in shaping the experiences of minority graduate students.

The significant finding on the role of faculty mentor is consistent with the notion of validation in a sense that "validation does not assume students can form connections on their own and asks college faculty and staff to take the initiative in reaching out to students to assist them to learn more about college, believe in themselves as learners, and have a positive college experience" [22] (p. 5). Rendon [22] pointed out that validation is different from involvement in which students take the initiative to get involved with campus life and take advantage of the services and programs offered by the institution. It is possible that faculty mentor provides the validation that graduate students of color need to gain access to the resources on campus and receive the social support they need to succeed. Further research is needed to gain a deeper understanding between faculty mentor and the validation provided through this process.

\subsection{The Role of Mentoring in Facilitating Student Success}

Mentors may positively impact the persistence of students of color if the agents emphasize academic achievement, value educational attainment, and validate their students' cultural backgrounds [58]. These institutional agents afford students access to institutionally-based knowledge and resources that would not be easily accessible without ties to these agents [30]. Unfortunately, when compared to Whites, racial minority students, namely Blacks and Hispanics, have smaller and less diverse networks [59].

Granovetter [60] suggested that two types of social relationships exist-those based on strong ties, which are densely knit and those based on weak ones. Strong ties, characterized by frequent interaction and intense emotional connections, can occur between relatives, close friends, and advisors, while weak ties exist between casual acquaintances. According to Granovetter [60], multiple factors, such as time, emotional intensity, and intimacy involved in a relationship, influence the strength of a tie. In their synthesis of social network research related to women of color in academe, Jean-Marie and Brooks [51] explain that both weak and strong ties can be beneficial to individuals. Weak ties, which are infrequent and not emotionally intense, can provide students with valuable information and resources. Low-density networks extend outside of one's social circles and may serve as a bridge between two separate but interconnected networks and provide information, such as professional development opportunities, job openings, research opportunities, financial aid, and other resources [51]. Students with few weak ties are subject only to the ideas and knowledge of their close friends and deprived of information and resources from acquaintances [60]. However, weak ties can still be beneficial to students as they provide access to social cliques that students may not otherwise have [61]. Faculty mentors can be instrumental in connecting students with a network of strong and weak ties.

The existence of strong social networks, including numerous weak ties, has been associated with positive educational experiences and attainment for racial minority students [31]. Because faculty mentors provide college students of color with the social capital—information and resources-that are instrumental in facilitating their success [31,49,50].

Gaining social capital through faculty mentors can lessen the impact of cultural and academic incongruity that students of color often experience in the college settings [22]. Rendon [22] (p. 4) explained that when students' backgrounds do not reflect those of upper and middle class in the college settings, "students face barriers and transitional problems crossing the academic border. 
Once underserved students cross into the college world, they often experience cultural incongruity in the form of alienation, marginalization, and possibly even cultural attacks such as stereotyping and discrimination". While the institution is making an effort to reduce the barriers caused by the disconnection between students' home world and academic world, unfortunately, these efforts are not always effectively utilized as indicated by the result of this study-many students of color not aware of and utilizing resources and student support services available on campus. Thus, in order to effectively provide services to students who need them the most, institutions must further examine various aspects of these programs including content, structure, and format to ensure accessibility.

\section{Conclusions}

The results of this study indicate that for graduate students enrolled at a Hispanic Serving Institution, factors such as a sense of personal achievement, family support, peer support, career promotion, supportive faculty, program satisfaction, and faculty mentor played an important role in their success. Specifically, for Latinos/as reported that faculty mentors played a greater role in their success compared to their non-Latino peers. In addition, Latinos/as were also more likely to use support services on campus than their non-Latino/a peers. These findings emphasize the importance of institutional support in bridging the social capital gap that is found among students of color and their White peers, and is critical to the success of graduate students. Several limitations found in this study include: (a) the relatively small sample size of graduate students, particularly Latinos/as; (b) the lack of qualitative data limited the researchers' ability to explore in detail the role faculty mentors play in facilitating graduate students' success. Future research studies should make every effort to address these challenges. Specifically, further investigation is needed to explore what and how institutional programs and infrastructure can be put in place to support the success of underrepresented graduate students.

Author Contributions: This paper was made possible with the contributions of the authors listed here. Natalie Tran and Gaetane Jean-Marie conceived and developed the conceptual framework for the paper; Natalie Tran and Katherine Powers developed the survey instrument and collected data; Sean Bell analyzed the data; Kimberly Sanders conducted the literature review.

Conflicts of Interest: The authors declare no conflict of interest.

\section{References}

1. Zusman, A. Challenges facing higher education in the twenty-first century. In American Higher Education in the Twenty-First Century: Social, Political, and Economic Challenges; Johns Hopkins University Press: Baltimore, MD, USA, 2005; Volume 2, pp. 115-160.

2. Carnevale, A.P.; Rose, S.J.; Strohl, J. Achieving racial and economic diversity with race-blind admissions policy. In Future of Affirmative Action: New Paths to Higher Education Diversity after FISHER v. University of Texas; McCourt School of Public Policy: Washington, DC, USA, 2014; pp. 187-202.

3. Harper, S.R.; Hurtado, S. Nine themes in campus racial climates and implications for institutional transformation. In Responding to the Realities of Race on Campus: New Directions for Student Services No. 120; Harper, S.R., Patton, L.D., Eds.; Jossey-Bass: San Francisco, CA, USA, 2007; pp. 7-24.

4. Harper, S.R. Black Male Student Success in Higher Education: A Report from the National Black Male College Achievement Study; University of Pennsylvania, Center for the Study of Race and Equity in Education: Philadelphia, PA, USA, 2012.

5. Hispanic Association of Colleges and Universities Fact sheet: Hispanic Higher Education and HSIs-2015. 2015. Available online: http://www.hacu.net/hacu/HSI_Fact_Sheet.asp (accessed on 1 December 2015).

6. Li, X. Characteristics of Minority-Serving Institutions and Minority Undergraduates Enrolled in These Institutions; U.S. Department of Education, National Center for Education Statistics, Institute of Education Sciences: Washington, DC, USA, 2007.

7. Sólorzano, D.G.; Villalpando, O.; Oseguera, L. Educational inequities and Latina/o undergraduate students in the United States: A critical race analysis of their educational progress. J. Hisp. High. Educ. 2005, 4, 272-294. [CrossRef] 
8. Zarate, M.E.; Burciaga, R. Latinos and college access: Trends and future directions. J. Coll. Admiss. 2010, 209, 24-29.

9. Kinzie, J.; Gonyea, R.; Shoup, R.; Kuh, G.D. Promoting persistence and success of underrepresented students: Lessons for teaching and learning. New Dir. Teach. Learn. 2008, 2008, 21-38. [CrossRef]

10. Palmer, R.T.; Maramba, D.C.; Dancy, T.E. A qualitative investigation of factors promoting the retention and persistence of students of color in STEM. J. Negro Educ. 2011, 80, 491-504.

11. Bastedo, M.N.; Gumport, P.J. Access to what? Mission differentiation and academic stratification in US public higher education. High. Educ. 2003, 46, 341-359. [CrossRef]

12. Gade, M.L. Four Multicampus Systems: Some Policies and Practices That Work. AGB Special Report; Association of Governing Boards of Universities and Colleges: Washington, DC, USA, 1993.

13. Altbach, P.G.; Gumport, P.J.; Berdahl, R.O. (Eds.) American Higher Education in the Twenty-First Century: Social, Political, and Economic Challenges; JHU Press: Baltimore, MD, USA, 2011.

14. Gutmann, A.; Ben-Porath, S. Democratic Education; John Wiley Sons, Ltd.: San Francisco, CA, USA, 1987.

15. Benjamin, R.; Carroll, S. Breaking the Social Contract: The Fiscal Crisis in Higher Education; Rand: Santa Monica, CA, USA, 1997.

16. Kuh, G.D.; Kinzie, J.; Schuh, J.H.; Whitt, E.J. Student Success in College: Creating Conditions that Matter; John Wiley Sons: San Francisco, CA, USA, 2010.

17. Grant, C.M. From chair to podium: A narrative experience of an African American female emerging scholar's entry into the academy. In The Duality of Women Scholars of Color: Transforming and Being Transformed in the Academy; Jean-Marie, G., Grant, C.M., Irby, D.J., Eds.; Information Age Publishing: Charlotte, NC, USA, 2014; pp. 1-32.

18. Rankin, S.R.; Reason, R.D. Differing perceptions: How students of color and white students perceive campus climate for underrepresented groups. J. Coll. Stud. Dev. 2005, 46, 43-61. [CrossRef]

19. Hart, J.; Fellabaum, J. Analyzing campus climate studies: Seeking to define and understand. J. Divers. High. Educ. 2008, 1, 222-234. [CrossRef]

20. Quaye, S.J.; Harper, S.R. (Eds.) Student Engagement in Higher Education: Theoretical Perspectives and Practical Approaches for Diverse Populations; Routledge: London, UK, 2014.

21. Nuñez, A.M.; Hurtado, S.; Galdeano, E.C. (Eds.) Hispanic-Serving Institutions: Advancing Research and Transformative Practice; Routledge: London, UK, 2015.

22. Rendón, L.I. Reconceptualizing success for underserved students in higher education. In National Postsecondary Education Cooperative; National Center for Education Studies: Washington, DC, USA, 2006.

23. Bourdieu, P. The forms of capital. In Handbook of Theory and Research for the Sociology of Education; Richardson, J.G., Ed.; Greenwood Press: New York, NY, USA, 1986; pp. 241-258.

24. Loury, G.C. A dynamic theory of racial income differences. In Women, Minorities, and Employment Discrimination; Wallace, P.A., LaMond, A.M., Eds.; Lexington Books: Lexington, MA, USA, 1977; pp. 153-186.

25. Portes, A. Social capital: Its origins and applications in modern sociology. Annu. Rev. Sociol. 1998, $24,1-24$. [CrossRef]

26. Coleman, J.S. Social capital in the creation of human capital. Am. J. Sociol. 1988, 94, S95-S121. [CrossRef]

27. Coleman, J.S. Foundations of Social Theory; Harvard University Press: Cambridge, MA, USA, 1990; p. 302.

28. Foley, M.W.; Edwards, B. Editors' introduction: Escape from politics? Social theory and the social capital debate. Am. Behav. Sci. 1997, 40, 550-561. [CrossRef]

29. Portes, A. The two meanings of social capital. Sociol. Forum 2000, 15, 1-12. [CrossRef]

30. Stanton-Salazar, R.D. Manufacturing Hope and Despair: The School and Kin Support Networks of U.S.-Mexican Youth; Teachers College: New York, NY, USA, 2001.

31. Museus, S.D.; Neville, K.M. Delineating the ways that key institutional agents provide racial minority students with access to social capital in college. J. Coll. Stud. Dev. 2012, 53, 436-542. [CrossRef]

32. Nuñez, A.M. Latino students' transitions to college: A social and intercultural capital perspective. Harv. Educ. Rev. 2009, 79, 22-48. [CrossRef]

33. Holland, N.E. Postsecondary education preparation of traditionally underrepresented college students: A social capital perspective. J. Divers. High. Educ. 2010, 3, 111-125. [CrossRef]

34. Palmer, R.; Gasman, M. "It takes a village to raise a child": The role of social capital in promoting academic success for African American men at a Black college. J. Coll. Stud. Dev. 2008, 49, 52-70. [CrossRef] 
35. Harper, S.R. Realizing the intended outcomes of Brown: High-achieving African American male undergraduates and social capital. Am. Behav. Sci. 2008, 51, 1030-1053. [CrossRef]

36. Park, J.J. It takes a village (or an Ethnic economy): The varying roles of socioeconomic status, religion, and social capital in SAT preparation for Chinese and Korean American students. Am. Educ. Res. J. 2012, 49, 624-650. [CrossRef]

37. Zhou, M.; Bankston, C.L., III. Social capital and the adaptation of the second generation: The case of Vietnamese youth in New Orleans. Int. Migr. Rev. 1994, 28, 821-845. [CrossRef]

38. Dayton, B.; Gonzalez-Vasquez, N.; Martinez, C.R.; Plum, C. Hispanic-serving institutions through the eyes of students and administrators. New Dir. Stud. Serv. 2004, 2004, 29-40. [CrossRef]

39. Grant, C.; Simmons, J. Narratives on Experiences of African American Women in the Academy: Conceptualizing Effective Mentoring Relationships of Doctoral Student and Faculty. Int. J. Qual. Stud. Educ. 2008, 21, 501-517. [CrossRef]

40. Tinto, V. Leaving College: Rethinking the Causes and Cures of Student Attrition, 2nd ed.; The University of Chicago Press: Chicago, IL, USA, 1993.

41. Crisp, G.; Nora, A. Hispanic student success: Factors influencing the persistence and transfer decisions of Latino community college students enrolled in developmental education. Res. High. Educ. 2010, 51, 175-194. [CrossRef]

42. Hurtado, S.; Ruiz, A. Realizing the Potential of Hispanic-Serving Institutions: Multiple Dimensions of Institutional Diversity for Advancing Hispanic Higher Education. 2012. Available online: http:/ / www.hacu.net/images/hacu/OPAI/H3ERC/2012_papers/Hurtado\%20ruiz\%20-\%20realizing\% 20the\%20potential\%20of\%20hsis\%20-\%20updated\%202012.pdf (accessed on 1 December 2015).

43. Benitez, M.; DeAro, J. Realizing student success at Hispanic-serving institutions. New Dir. Community Coll. 2004, 2004, 35-48. [CrossRef]

44. Bettinger, E.P.; Long, B.T. Remediation at the community college: Student participation and outcomes. New Dir. Community Coll. 2005, 2005, 17-26. [CrossRef]

45. Rendon, L.I. Validating culturally diverse students: Toward a new model of learning and student development. Innov. High. Educ. 1994, 19, 33-51. [CrossRef]

46. Santos, S.J.; Reigadas, E.T. Latinos in higher education: An evaluation of a university faculty mentoring program. J. Hisp. High. Educ. 2002, 1, 40-50. [CrossRef]

47. Waldeck, J.H.; Orrego, V.O.; Plax, T.G.; Kearney, P. Graduate student/faculty mentoring relationships: Who gets mentored, how it happens, and to what end. Commun. Q. 1997, 45, 93-109. [CrossRef]

48. Dika, S.L. Relations with faculty as social capital for college students: Evidence from Puerto Rico. J. Coll. Stud. Dev. 2012, 53, 596-610. [CrossRef]

49. Fontaine, T.P. The impact of faculty-student interaction on Black doctoral students attending historically Black institutions. J. Negro Educ. 2008, 81, 136-147. [CrossRef]

50. Rios-Aguilar, C.; Deil-Amen, R. Beyond getting in and fitting in: An examination of social networks and professionally relevant social capital among Latina/o university students. J. Hisp. High. Educ. 2012, 11, 179-196. [CrossRef]

51. Jean-Marie, G.; Brooks, J.S. Mentoring and supportive networks for women of color in academe. In Women of Color in Higher Education: Contemporary Perspectives and New Directions; Emerald Group Publishing Limited: Bingley, UK, 2011; Volume 10, pp. 91-108.

52. Astin, A.W. Student involvement: A developmental theory for higher education. J. Coll. Stud. Pers. 1984, 25, 297-308.

53. Crisp, G.; Cruz, I. Mentoring college students: A critical review of the literature between 1990 and 2007. Res. High. Educ. 2009, 50, 525-545. [CrossRef]

54. Katz, J.; Harnett, R.T. (Eds.) Scholars in the Making; Ballinger: Cambridge, MA, USA, 1976.

55. Marsden, P.V. Homogeneity in confiding relations. Soc. Netw. 1988, 10, 57-76. [CrossRef]

56. Avery, C.M.; Daly, A.J. Promoting equitably educational outcomes for high-risk college students: The roles of social capital and resiliency. J. Equity Educ. 2010, 1, 46-70.

57. Benismon, E.M. The underestimated significance of practitioner knowledge in the scholarship on student success. Rev. High. Educ. 2007, 30, 441-469. [CrossRef]

58. Museus, S.D.; Quaye, S.J. Toward an intercultural perspective of racial and ethnic minority college student persistence. Rev. High. Educ. 2009, 33, 67-94. [CrossRef] 
59. Martin, J.P.; Simmons, D.R.; Yu, S.L. The role of social capital in the experiences of Hispanic women engineering majors. J. Eng. Educ. 2013, 102, 227-243. [CrossRef]

60. Granovetter, M. The strength of weak ties: A network theory revisited. Sociol. Theory 1983, 1, $201-233$. [CrossRef]

61. Burt, R.S. A note on social capital and network content. Soc. Netw. 1997, 19, 355-373. [CrossRef]

(C) 2016 by the authors; licensee MDPI, Basel, Switzerland. This article is an open access article distributed under the terms and conditions of the Creative Commons Attribution (CC-BY) license (http:/ / creativecommons.org/licenses/by/4.0/). 